\title{
Internal Analysis of Factors Influencing the Use of Sleeping Beds (Utility Rate)
}

\author{
Trimo, Sandu Siyoto, Siti Farida \\ Caruban Hospital, Madiun, \\ Indonesia \\ Email: \\ diklattrimo@gmail.com
}

Received : March 12, 2019

Accepted : October 13, 2019

Published : November 26, 2019

\begin{abstract}
Good service will increase the utilization of hospitalization (Utility rate) in Hospital, the factors that influence the utilization of service are procedure of service, service of doctor and nurse as well as facilities and infrastructure that exist in Hospital. The purpose of this study is to internal analysis of factors that affect the utilization of inpatient beds (Utility rate) in Caruban Hospital Madiun District. This research design using descriptive quantitative with Cross Sectional approach. The sample in this study amounted to 133 respondents. Random sampling sampling technique. The research instrument used questionnaire with Ordinal regression statistic test with $\alpha=0,05$. As many as $60.2 \%$ (80 respondents) stated that the service procedure is in good category. 50.4\% (67 respondents) stated that the Doctor Service at Caruban Hospital of Madiun Regency is good. 81.2\% (108 respondents) stated that Nurse Service is in good category. $45.9 \%$ (61 respondents) stated that the facilities and infrastructure in the category is quite good. $60.2 \%$ (80 respondents) stated that the utilization of the bed at Caruban Hospital of Madiun Regency is good. There is no influence of service procedure, there is influence of doctor service, nurse service and facility and infrastructure with utilization of inpatient bed (Utility rate) at RSUD Caruban Regency of Madiun. With good service from doctors and nurses as well as facilities that support the patient will provide information to families, relatives and others to take advantage of existing health services in hospitals Caruban Madiun District.
\end{abstract}

Keywords: Factors influencing, sleeping beds

\section{cc) (1) (?)}

This is an open-acces article distributed under the terms of the Creative Commons Attribution-ShareAlike 4.0 International License. 


\section{INTRODUCTION}

Public awareness of the importance of health is increasing, this means the demand for health services will increase, but hospitals as part of health care facilities have not been utilized by the community. Measuring the performance of a hospital can be known through several indicators. The most commonly used indicators are Bed Occupancy Rate (BOR), Average Length of Stay (ALOS), Bed Turn Over (BOT), Turn Over Internal (TOI), Net Death Rate (NDR), Gross Death Rate (GDR), and average clinic visit per day (MOH RI, 2015).

Utilization of hospitalization in hospital or patient satisfaction can be described by BOR Hospital data. Bed Occupancy Rate (BOR) is one of the hospital's performance indicators that states the percentage of bed usage in one unit of time. This indicator provides an overview of the low level of hospital bed utilization. The ideal BOR value is $60-85 \%$. The low BOR indicates that the patient's decision to utilize hospitalization at Rumah Sakiut is still low. Low BOR data is one of the basic management to make efforts to improve the efficiency of beds in the hospital and at the same time can be used for evaluation and planning of hospital resources, including Caruban District Hospital Madiun.

The BOR figures of Caruban hospitals from year to year do not show a fixed value, or may increase but then decrease again, suggesting that the ups and downs are varied or unstable. The occupancy rate (BOR) for the last ten years. The ideal BOR score according to the Ministry of Health is between 60-85\% (MOH RI, 2015).

Initial preliminary study conducted On December 5, 2017, on 20 patients who were hospitalized at Caruban Hospital of Madiun Regency about the patient's service procedure, 14 people said the service procedure was good starting from the registration until the patient was in hospital and 6 patients said that was enough either because the service is still queued pharmacy long. For the services of doctors as many as 13 people said that the doctor's service was good and 4 people said good enough and 3 people said less well the reason doctors are not on time when doing the patient examination. For nurse service as many as 18 people said that nurse service is good and only 2 people say good enough. For facilities and infrastructure as many as 12 people said that the facilities in the hospital is complete and as many as 8 people say less complete.

Some approaches can be used to determine the factors that affect the BOR rate of a hospital. The approaches are: utility analysis, market analysis (marketing) and system approach analysis. The utility analysis emphasizes the BOR approach with the facilities provided or offered by the hospital to the patient, the market analysis focuses on the BOR approach with the marketing review from the consumer point of view, while the system analysis reviews the BOR through hospital operations as a system that includes stage input, process and output. Seeing the problems at the hospital either at the part or overall level it will be easier and representative to review the BOR through system analysis. (Sulistyono, 2012).

To be able to provide good service a hospital must meet some standard requirements that include input standards, process standards and output standards (Donabedian, 2008). The input factor consists of the elements of the means. infrastructure, personnel, methods and budgets. To meet the standards of the process should be considered processes that occur such as nursing care process, service delivery process, service time, continuity of service. While including the standard output for example is the indicators that can be used to measure the performance of the Hospital in this case including Bed Occupancy Rate (BOR). The purpose of this study is to identify what factors affect the utilization of inpatient beds (Utility rate) at Caruban Hospital Madiun District.

\section{MATERIALS AND METHODS}

This research design using descriptive quantitative with Cross Sectional approach. The sample in this study amounted to 133 respondents. Random sampling sampling technique. The research instrument used questionnaire with Ordinal regression statistic test with $\alpha=0,05$.

\section{RESULT}

\section{Characteristics of the Subject}

Table 1. Characteristics of respondents in this study include age, gender, education, occupation, length of care, procedure of service, doctor service, nursing service, facilities \& infrastructure and bed utilization. 


\begin{tabular}{|c|c|c|c|}
\hline No. & Characteristic & $\mathbf{\Sigma N}$ & $\Sigma \%$ \\
\hline \multirow{5}{*}{1} & Age (year) & & \\
\hline & $<20$ & 24 & 18 \\
\hline & $20-35$ & 55 & 42 \\
\hline & $36-55$ & 35 & 26 \\
\hline & $>55$ & 19 & 14 \\
\hline \multirow{3}{*}{2} & Gender & & \\
\hline & Man & 54 & 41 \\
\hline & Female & 79 & 59 \\
\hline \multirow{5}{*}{3} & Education & & \\
\hline & Elementary school & 12 & 9 \\
\hline & Junior high school & 20 & 15 \\
\hline & Senior high school & 67 & 50 \\
\hline & University & 34 & 26 \\
\hline \multirow{5}{*}{4} & Occupation & & \\
\hline & Housewife & 20 & 15 \\
\hline & Entrepreneur & 44 & 33 \\
\hline & Employees & 32 & 24 \\
\hline & Gov. employees & 37 & 28 \\
\hline \multirow{4}{*}{5} & length of care (day) & & \\
\hline & $3-4$ & 48 & 35 \\
\hline & $5-7$ & 59 & 42 \\
\hline & $>7$ & 32 & 23 \\
\hline \multirow[t]{4}{*}{6} & Procedur of service & & \\
\hline & Less & 13 & 9,8 \\
\hline & Enough & 40 & 30,1 \\
\hline & Good & 80 & 60,2 \\
\hline \multirow[t]{4}{*}{7} & Doctor service & & \\
\hline & Less & 15 & 11,3 \\
\hline & Enough & 51 & 38,3 \\
\hline & Good & 67 & 50,4 \\
\hline \multirow[t]{4}{*}{8} & Nurse service & & \\
\hline & Less & 7 & 5,3 \\
\hline & Enough & 18 & 13,5 \\
\hline & Good & 108 & 81,2 \\
\hline \multirow[t]{4}{*}{9} & Facilities \& infrastructure & & \\
\hline & Less & 26 & 19,5 \\
\hline & Enough & 61 & 45,9 \\
\hline & Good & 46 & 34,6 \\
\hline \multirow[t]{5}{*}{10} & Bed utilization & & \\
\hline & Less & 12 & 9 \\
\hline & Enough & 41 & 40,8 \\
\hline & Good & 80 & 60,2 \\
\hline & Total & 133 & 100 \\
\hline
\end{tabular}

Based on table 1 above, it is known that from a total of 133 respondents, $42 \%$ (55 people) are 20-35 years old, 59\% (79 people) are female, 50\% (67 people) have high school education, 33\% (44 people) as an entrepreneur, $42 \%$ (59 people) were admitted for 5-7 days, $60.2 \%$ (80 people) stated that the service procedure was in good category, $50.4 \%$ (67 people) stated that the Doctor Service at Caruban Hospital of Madiun Regency Well, 81,2\% (108 people) stated that Nurse Service at RSUD Caruban Regency of Madiun is good, Facilities and infrastructure in enough category and 60,2\% (80 people) stated that Utilization of bed at RSUD Caruban Regency of Madiun good. 
Table 2. Ordinal statistical test results of internal analysis of factors affecting utilization of inpatient beds (Utility rate) at RSUD Caruban Madiun District, 27 February - 25 March 2018.

\begin{tabular}{lc}
\hline Ordinal orreinal analysis & Signification \\
\hline Procedure service with bed utilization & 0,299 \\
\hline Doctor service with bed utilization & 0,018 \\
\hline Nurse service with bed utilization & 0,005 \\
\hline Facilities and infrastructure with bed utilization & 0,000 \\
\hline
\end{tabular}

From the statistical test on the service procedure with the utilization of the bed obtained significance value is $p=0.299$ which means greater than the value $\alpha=0.05(p=0.299>\alpha=0.05)$ means accept Ho, the conclusion there is no effect of service procedures with the utilization bed Utility rate (Utility rate) in RSUD Caruban Madiun District.

From the result of statistical test on physician service with bed utilization, the value of significance is $p$ $=0,018$ which means smaller than $\alpha=0,05(\mathrm{p}=0,018<\alpha=0.05)$ means reject Ho, the conclusion there is influence of doctor service with place utilization sleep inpatient (Utility rate) at Caruban Hospital of Madiun Regency.

From the results of statistical tests on nursing services with bed utilization obtained significance value is $p=0.005$ which means smaller than the value of $\alpha=0.05(p=0.005<\alpha=0.05)$ means reject Ho, the conclusion is the influence of nurse services with the use of place sleep inpatient (Utility rate) at Caruban Hospital of Madiun Regency.

From the result of statistical test on facilities and infrastructure with bed utilization, the significance value is $p=0.000$ which means bigger than value $\alpha=0,05(p=0,000<\alpha=0.05)$ means reject $\mathrm{Ho}$, the conclusion there is influence of facilities and infrastructure with utilization of inpatient bed (Utility rate) at Caruban Hospital of Madiun Regency

\section{DISCUSSION}

\section{Procedure Service At RSUD Caruban Madiun Regency According To Respondents}

The results showed that most respondents $60.2 \%$ (80 respondents) stated that the service procedure in RSUD Caruban Madiun good. Hospitals as health facilities that provide health services to the public have a very strategic role in accelerating the improvement of health health status of the community. Hospitals are required to provide quality services in accordance with established standards or procedures and can be reached by all levels of society. Standards are the ideal or highest level of achievement and perfect that is used as a minimum acceptance limit (Aditamar, 2013). From the results of this study shows that the existing service procedures in Caruban Hospital according to the respondents have been good.

From the above description, the researcher argues that the procedure of service provided by the Hospital is good. The service procedure here is to provide good services such as administrative services, outpatient services, inpatient services, emergency services either general patients or insurance patients or BPJS. The alignment of health services to patients in providing the expected needs is not an easy thing, when patients come with illness suffered in acute conditions and should be rescued or elective services (planned) will experience disappointment when it comes to the hospital meet with the registration officer did not get a place sleep (room care), this is often faced daily in patient care at the hospital.

\section{Doctor Service at Caruban Regional Hospital of Madiun Regency According To Respondents}

The results showed that most respondents 50.4\% (67 respondents) stated that the Doctor Services in Caruban Hospital of Madiun Regency is good. Doctors are the most influential element in determining the quality of hospital services to patients. Doctors can be considered the heart of a hospital. Its main function is to provide medical services to patients with the best possible quality by using procedures and techniques based on medical science and ethics that apply and can be accounted for (Aditama, 2013). The physician's technical skill that has been in accordance with expectations makes the patient to be loyal to the hospital so that the growing interest to come back for treatment at the hospital. Patients will feel comfortable served by doctors who are able to build good interpersonal 
relationships with patients. Having a sense of comfort will make patients happy handled by the doctor concerned and not reluctant to come back to the same doctor for treatment when experiencing health problems (Pohan, 2013). Good doctor's service will make the patient feel satisfied with the health service and think to use the health service again when need it.

Everyone's perceptions change depending on what they judge and how they judge. Because perceptions are influenced by several factors, Jacobalis (2010) argues that consumer perceptions of service quality are influenced by several factors including age, sex, occupation, education level, socioeconomic, cultural, physical environment and personality and patient experience. Education is concerned with the need to seek health services. Education affects what will be done. This is reflected in the knowledge, attitudes and behavior of low education associated with the use of low health services. One's education will affect the awareness of the importance of healthy means to oneself and the environment so as to encourage the need for health care and the selection of health services (Andersen, 2010). The service of doctors influences the decision in menafaatkan health services although most of the services of doctors either, but there are some points that indicate that respondents who are not satisfied with the services of doctors are doctors do not know the type of disease and treatment procedure and there are a small number of respondents who stated that doctors do not explain the action to be performed.

From the above description, the researcher argues that the service of doctors in Caruban Hospital of Madiun Regency can be proved from the seriousness of the doctor in listening to the patient's complaint and the doctor does not differentiate in the provision of health services, but there are a small number of respondents who stated that the doctor did not explain the action done and does not explain the disease as well as the procedure of action that has been done. The perception and behavior of the patient is influenced by education, work, socioeconomic and cultural factors that are already inherent among the society in utilizing health services.

\section{Nurse Service At Caruban Regional Hospital of Madiun Regency According To Respondents}

The results showed that most respondents $81.2 \%$ (108 respondents) stated that the Nurse Service at Caruban Hospital of Madiun Regency is good. The attitude of nurses in providing services is a variable that has a priority scale to be improved by the management of the hospital. Keep in mind that the hospital is a business unit in the field of services, so the quality of service will determine the success of its activities. While the nurse is a hospital party that is directly related to the patient as a consumer (Azwar, 2010). Awareness of the medical personnel for efficient service of inpatients will give a good impression on the patient.

The results of research proposed by Hayati (2010) in his research that if the nurse is not caring in providing nursing services to patients will have a negative impact on patients so that patients will feel fear, worry, lost control, and despair. In addition, patients will feel tersaing, feel no one will help, and the possibility of pain will increase, the patient's healing process will be longer, and interpersonal relationships nurses and pasein not well established. According to the researcher attitude is an important aspect that should be done by nurses in nursing practice. Nursing services based on attitudes shown or performed effectively can promote health and improve the quality of health services.

From the above description, the researcher argues that most of the respondents stated that the nurse service at Caruban Regional Hospital of Madiun Regency is good, it is indicated by the nurses to serve the patient with friendly and polite in giving therapy and doing the service, but not all respondents stated that the service Well, there is a small percentage of respondents who say that nursing service is lacking, as in helping to meet the spiritual needs is considered by a small minority of respondents is still lacking. This can be understood because in providing spiritual needs in the hospital there is a team of its own to meet the spiritual needs of patients.

\section{Facilities And Infrastructure At Caruban Regional Hospital Of Madiun Regency}

The results showed that almost half of respondents $45.9 \%$ (61 respondents) stated that the facilities and infrastructure at Caruban Regional Hospital of Madiun Regency is quite good. Health service infrastructure facilities can be defined as a process of cooperation efficient utilization of all health facilities and infrastructure to provide professional services in the field of facilities and infrastructure in the process of effective and efficient health services as well (Muhammad, 2010). 
Completeness of good infrastructure is very important in creating customer satisfaction. Febriani (2012) which states that the quality of services more difficult to evaluate compared with the quality of goods. By means of good infrastructure then the utilization of the bed will also increase, because the patient feels his health will be guaranteed by the means of complete infrastructure.

From the above description the researchers argue that the facilities and infrastructure that exist in the Hospital is good enough, but there are some that must be improved according to the respondent's statement such as the cleanliness of the bathroom and also the facility of health equipment also needs to be improved. Consumers will decide to use or utilize health service advice based on the behavior of the factors that affect it. Hospital hygiene and sanitation programs cost a lot, so often the director / management of the hospital less agree with the reasons of budget constraints. Though this antimicrobial resistance control program actually provides many benefits, such as reducing the risk of surgery, chemotherapy, and long-term benefits to prevent the occurrence of total resistance or the return of the medical world to the era before antibiotics. In addition to key hand hygiene, safety, surface surface cleanliness over time, easy access, heating, ventilation and air conditioning, and water governance are used to play an important role in protecting officers and patients.

\section{Utilization Of Bed In RSUD Caruban Madiun Regency}

The results showed that most respondents $60.2 \%$ (80 respondents) stated that the utilization of beds in Caruban Hospital Madiun Regency good. To know the level of benefit, quality and effisiensi of hospital service needed an indicator. In addition to the existing information can be meaningful there must be a parameter value that will be used as an appeal value between the facts with the desired standard. Utilization of hospitalization in hospital or patient satisfaction can be described by BOR Hospital data. Bed Occupancy Rate (BOR) is one of the hospital's performance indicators that states the percentage of bed usage in one unit of time. This indicator provides an overview of the low level of hospital bed utilization. The ideal BOR value is $60-85 \%$. The low BOR indicates that the patient's decision to utilize hospitalization at Rumah Sakiut is still low. Low BOR data is one of the basic management to make efforts to improve the efficiency of beds in the hospital and at the same time can be used for evaluation and planning of hospital resources, including Caruban District Hospital Madiun.

From the above description, the researcher believes that in the utilization of bed, $60.2 \%$ of respondents stated that the utilization of the bed is good. Patients who are satisfied with the health service because of the various factors encourage to use the existing bed in the hospital and inform others so that the BOR level in the hospital will also increase.

\section{The most influential factor analysis on utilization of inpatient bed (Utility rate) in RSUD Caruban Madiun Regency.}

The result of statistical test on the service procedure with the utilization of the bed obtained significance value is $p=0.299$ which means greater than the value $\alpha=0.05(p=0.299>\alpha=0.05)$ means accept Ho, the conclusion there is no effect of service procedures with the use of place sleep inpatient (Utility rate) at Caruban Hospital of Madiun Regency.

Inpatient by Crosby in Nasution (2015) is an ongoing patient activity to the hospital to obtain health services lasting more than 24 hours. In particular, inpatient services aimed at patients or patients who require continuous nursing care (Continous Nursing Care) until healing occurs. Hospital service procedure is very important to clarify the existing service in Hospital, but this service procedure is less understood by society, and this service procedure more ccoknya for Hospital employees to them in running health service in accordance with procedure applied Hospital. So from the results of the study many respondents stated that the hospital service procedure is good but there is no effect on the utilization of inpatient bed (utylity rate).

\section{CONCLUSION}

There is no effect of service procedure with inpatient bed utilization. There is influence of doctor service with utilization of bed of inpatient. There is influence of nurse service with utilization of bed of inpatient. there is influence of facilities and infrastructure with utilization of inpatient bed (Utility rate) in RSUD Caruban Madiun Regency. 


\section{REFERENCES}

Achmadi, Abu, \& Cholid, N. (2013). Metodologi Penelitian. Jakarta: Bumi. Aksara.

Aditama. (2013). Tiga aspek penilaian mutu pelayanan. http://mutupelayanan kesehatan.net/index.php/component/content/article/19-headline/1194-tiga-aspek-penilaianmutu-pelayanan. Diakses pada tanggal 11 November 2017.

Almatsier. (2012). Prinsip Dasar Ilmu Gizi. Jakarta. Gramedia Pustaka.

Andersen. (2010). Manajemen Pemasaran. Edisi Kesebelas Jilid 2, Jakarta; PT. Index.

Arikunto, \& Suharsini. (2014). Prosedur Penelitian Suatu Pendekatan Praktik. Rineka Cipta. Jakarta.

Austin. (2011). Agroindustrial Project Analysis. The John Hopkins University Press. London.

Ayunda. (2009). Gambaran Kepuasan terhadap Pelayanan Dokter di Rumah Sakit Tugu Ibu Depok Tahun 2009: Thesis. Sarjana FKMUI. Depok.

Azwar. (2010). Penyusunan Skala Psikologi. Jakarta: Pustaka Pelajar

Depkes RI. (2014). Pedoman Pengelolaan Rekam Medis Rumah Sakit di Indonesia. Jakarta: Departemen Kesehatan RI.

Depkes RI. (2015). Buku Petunjuk Pengisian, Pengolahan,dan Penyajian Data Rumah Sakit. Jakarta: Depkes RI.

Direktorat Jendral Pelayanan Medik. (2013). Pedoman Penyelenggaraan Pelayanan Rumah Sakit. Jakarta: Departemen Kesehatan Republik Indonesia.

Donabedian. (2008). The Definition of Quality and Approaches to Its Assessment, Volume 1: Explorations in Quality Assessment and Monitoring, Health Administration Press, Ann Arbor.

Febriani. (2012). Pengaruh Keter-sediaan Sarana Prasarana, Kualitas Transportasi Terhadap Kepuasan Wisatawan, eprints.upn.ac.id/222/1 /jurnal-manaje-men-3-2. Pdf.

Hidayat. (2012). Riset Keperawatan dan Teknik Penulisan Ilmiah. Salemba Medika: Edisi 2.

Iskandar. (2012). Asuhan Keperawatan Jiwa. Bandung: PT Refika. Aditama.

Kepmenkes RI. (2008). Keputusan Menteri Kesehatan No. 129/Menkes/SK/II/2008 Tentang SPM RS.

Muhammad. (2010). Pedoman Teknis Sarana dan Prasarana rumah Sakit kelas C. Bandung: Afabeta.

Nasution. (2015). Manajemen Mutu Terpadu. 2015. Bogor. Ghalia Indonesia.

Notoadmodjo. (2010). Metodologi Penelitian Kesehatan. Jakarta: Rineka Cipta.

Nursalam. (2015). Metodologi Penelitian Ilmu Keperawatan Pendekatan Praktis edisi 4. Jakarta: Salemba Medika.

Jati, P. (2009). Beberapa Konsep Dasar tentang Manajemen Rumah Sakit. Prasetijo, Jakarta: PT Gramedia Pustaka Utama.

Rekam Medis RSUD Caruban (2017). Medical Record Management RSUD Caruban. 
Singgih. (2010). Reformasi Pelayanan Publik, Teori, Kebijakan, dan Implementasi, Jakarta. Bumi Aksara.

Sugiono. (2011). Metode Penelitian Kuantitatif, Kualitatif dan R\&D. Bandung: Afabeta.

Sulistyono. (2012). Konstruksi Alat Ukur Psikologi. Pusat Pengembangan Bahan Ajar. Bandung; Mercu Buana.

Syaaf. (2015). Manajemen Sumber Daya Manusia. Jakarta: Bumi. Aksara.

Wolfer. (2011). Pedoman Teknis Prasarana Rumah Sakit Sistem Proteksi. Jakarta: Bumi Aksara 